\title{
The proposition of a new method to convert formalin cadavers to academic and
}

\section{museology purposes}

\author{
Proposição de um novo método para converter cadáveres formolizados para utilização acadêmica e \\ museológica
}

Propuesta de un Nuevo método para convertir cadáveres formalizados para uso académico y museológico

Received: 12/29/2020 | Reviewed: 01/06/2021 | Accept: 01/07/2021 | Published: 01/08/2021

Amanda Teixeira Prata

ORCID: https://orcid.org/0000-0002-9035-1730

Universidade Federal do Espírito Santo, Brazil E-mail: amandatprata@hotmail.com

Josemberg da Silva Baptista

ORCID: https://orcid.org/0000-0003-0514-8170

Universidade Federal do Espírito Santo, Brazil

E-mail: josemberg.baptista@ufes.br

\begin{abstract}
The embalming of a cadaver to study anatomy in humans, animals, and for expositions in biological museums is classically performed by formaldehyde injection. Despite its efficiency and wide application, this method delivers technical problems and high toxicity. Through an experimental model with Wistar rats previously embalmed in formalin, we developed two converting solutions (G1 and G2) to perform a macroscopic and qualitative analysis of the embalming maintenance, the color, the fungus proliferation, the pliability, and the post-conversion dissection of the specimens. This work aims to present the results of this experiment and discuss the data. After 365 days of the experiment, both solutions showed benefits in terms of reduction of toxicity, the use of a single solution to convert, storage without the need for containers with embalming solution, containment of fungus proliferation, and improvement of the color of the organs. Although these are the initial results without full achievement, we consider the G1 solution a suitable and advantageous alternative for the museology area.
\end{abstract}

Keywords: Embalming; Wistar rats; Formaldehyde; Anatomy; Museums.

\section{Resumo}

A fixação de peças cadavéricas para o estudo da anatomia humana, animal, e para exposições em museus de biologia é classicamente realizada por meio da injeção de solução de formaldeído. Apesar da sua eficiência e larga aplicação, a utilização dessa técnica revela problemas técnicos e relativos a toxicidade. Através de um modelo experimental utilizando ratos Wistar previamente fixados com formaldeído, elaboramos e testamos duas soluções conversoras (G1 e G2) para analisar macroscopicamente e qualitativamente a toxicidade, a manutenção da fixação da peça, a coloração das estruturas anatômicas, a proliferação fúngica e a flexibilidade das estruturas para possível dissecação pósconversão. O objetivo desse trabalho é apresentar os resultados preliminares desse experimento. Após 365 dias de experimento, ambas as soluções demonstraram benefício quanto: diminuição da toxicidade ao odor, utilização de solução única em peças já formolizadas, armazenamento sem necessidade de tanques contendo líquido fixador, contenção da proliferação fúngica e melhora da coloração. Embora o resultado preconizado inicialmente não tenha sido alcançado, consideramos a solução utilizada em G1 uma alternativa vantajosa para área de museologia.

Palavras-chave: Fixação; Rato Wistar; Formol; Formaldeído; Anatomia; Museus.

\section{Resumen}

La fijación de piezas cadavéricas para el estudio de la anatomía humana, animal y para exposiciones en museos de biología se realiza clásicamente mediante la inyección de solución de formaldehído. A pesar de su eficacia y amplia aplicación, el uso de esta técnica revela problemas técnicos y de toxicidad. Mediante un modelo experimental utilizando ratas Wistar previamente fijadas con formaldehído, desarrollamos y probamos dos soluciones convertidoras (G1 y G2) para analizar macroscópicamente y cualitativamente la toxicidad, manteniendo la fijación de la pieza, la coloración de estructuras anatómicas, proliferación fúngica y flexibilidad de las estructuras para una posible disección posterior a la conversión. El objetivo de este trabajo es presentar los resultados preliminares de este experimento. Luego de 365 días de experimentación, ambas soluciones mostraron beneficios en cuanto a: reducción de la toxicidad 
por olor, uso de una sola solución en piezas ya formalizadas, almacenamiento sin necesidad de tanques que contengan líquido fijador, contención de la proliferación de hongos y mejora del color. Aunque no se ha logrado el resultado inicialmente recomendado, consideramos que la solución utilizada en G1 es una alternativa ventajosa para el área de museología.

Palabras clave: Fijación; Rata Wistar; Formaldehído; Anatomia; Museos.

\section{Introduction}

In the contexts of health colleges and biological museums, the use of human and animal cadavers occurs as a tool for education as well as to inspire future generations. Despite the modern virtual alternatives in education, the visualization and manipulation of cadavers remain as the gold standard in this matter, considered distinct, and there is still no viable alternative to change, especially in the surgical and clinical training (Burns et al., 2018; Hayashi et al., 2014; Homma et al., 2019; Patel \& Moxham, 2008).

Most of the human anatomy laboratories in Brazil inject a formalin solution in $10 \%$ to embalm cadavers and keep them immersed in the same solution for maintenance. Such procedures allow to avoid microbial proliferation, decomposition, and its efficiency is vastly recognized and long-lasting. However, this routine results in an unhealthy environment for professionals and students (Rodrigues et al., 2010) due to the high toxicity and degree of carcinogenesis of formaldehyde(International Agency for Research on Cancer, 2006). Although the harmful effects are related to the concentration and the exposure time, eye irritations, mucosal irritations, and skin lesions occur with a simple contact with the substance (Lorenzoni et al., 2017; Tamayo-Arango \& Garzón-Alzate, 2018).

In the biological museums, these aspects are more controlled and even attenuated with other methods, such as ethanol embalming, hermetically sealed containers, and controlled ventilation, even though the ethanol is highly flammable (Baptista et al., 2010; Hammer et al., 2012).

Despite the great advancement of the primary methods in cadaver embalming with regular durability (Brenner, 2014; Hammer et al., 2015; Lombardero et al., 2017), there is a lack of knowledge about methods to convert or adapt formaldehydeembalmed cadavers to teach and to use in extension activities in the university (Chafin et al., 2013; Gilbert et al., 2007; Yörükoglu et al., 2013).

This work aims to present and discuss results from two solutions used to convert biological specimens embalmed in formalin $(10 \%)$. Our original intention was to create a single solution capable to reduce toxicity and provide maintenance without the need for immersion and microbial control, to preserve the characteristics of flexibility, texture, and color of the anatomical structures, such in the living.

\section{Methodology}

This work was ethically reviewed and approved by the Institutional Ethical Committee in Animals (CEUA-UFES 15/2014). Twelve male Wistar rats (Rattus norvegicus) with a mean age of 600 days and a mean weight of $320 \mathrm{~g}$ were obtained from the animal colony of the Centro de Ciencias da Saude - UFES. These animals were euthanized with an overdose of sodium pentobarbital $(100 \mathrm{mg} / \mathrm{kg})$ and dissected in the sagittal plane to expose their cavities (Figure 1). The standard embalming in $10 \%$ of formalin (standard solution) was performed through the left ventricle with pump perfusion. Thus, they were randomly divided into two experimental groups, G1 and G2.

Each group provided 1 specimen to serve as Control, which was kept immersed in the standard solution until the end of the experiments - this methodology was employed to simulate the routine of the persistent majority of the anatomy laboratories in Brazil. The others were prepared individually using two experimental solutions (Table 1). 
Figure 1 - Photographs of the specimens of Control group (C), G1, and G2 after 365 days of the experiment.
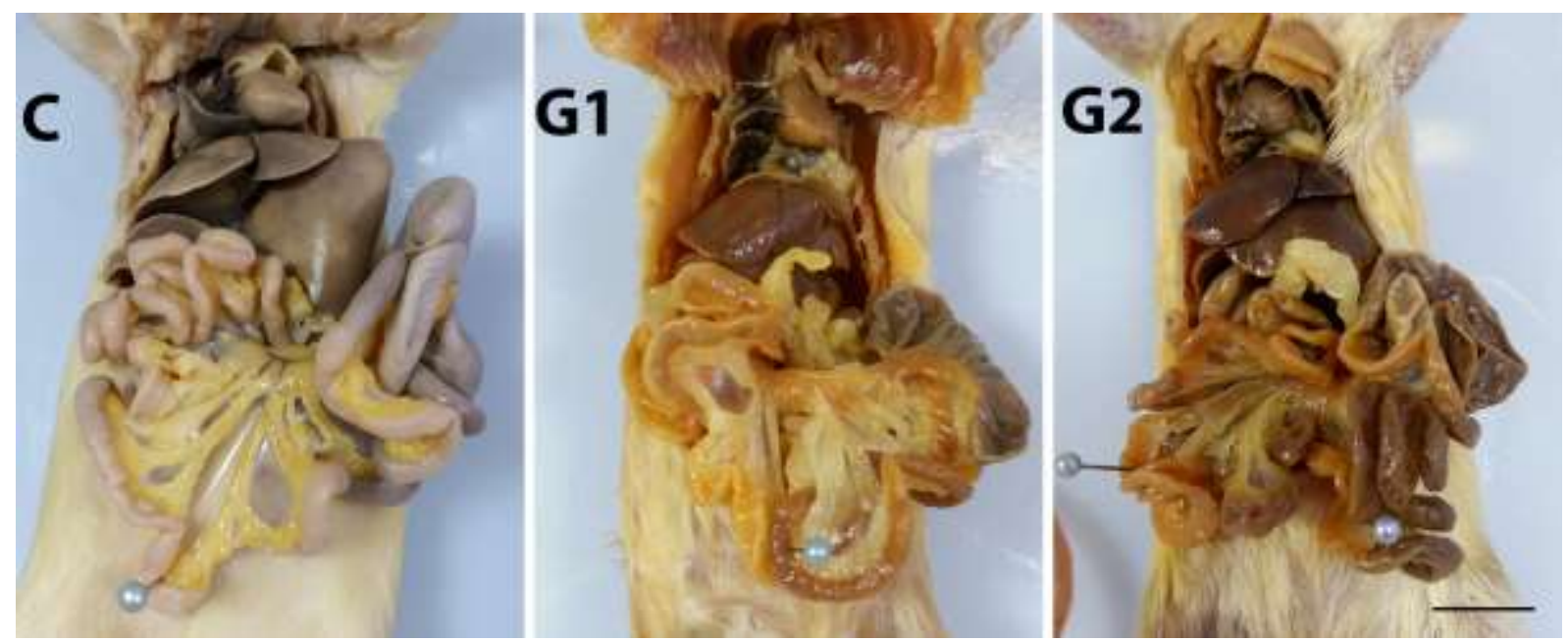

Note the absence of fungus or signs of decomposition, and the difference in color over the methods studied. Scale bar $2 \mathrm{~cm}$. Source: Authors.

Table 1 - Experimental groups and proposed solutions.

\begin{tabular}{|c|c|c|}
\hline Groups & G1 (6 specimens) & G2 (6 specimens) \\
\hline Control specimens & 1 & 1 \\
\hline Experimental specimens & 5 & 5 \\
\hline $\begin{array}{c}\text { Solutions } \\
\text { (2 liters for each specimen) }\end{array}$ & $\begin{array}{l}30 \% \text { water } \\
2 \% \text { sodium chloride } \\
43 \% \text { glycerin } \\
25 \% \text { ethanol in } 96 \text { degrees } \\
\text { pH } 4\end{array}$ & $\begin{array}{l}10 \% \text { water } \\
10 \% \text { isothiazolinones and } \\
\text { halogenated derivatives } \\
37 \% \text { glycerin } \\
43 \% \text { ethanol in } 50 \text { degrees. } \\
\text { pH } 7,6 \text { after } 28 \mathrm{~g} \text { sodium phosphate }\end{array}$ \\
\hline
\end{tabular}

Source: Authors.

Since the proposed solution has a fatty characteristic, the G1 and G2 specimens were kept individually in a closed recipient following their solution for 30 days at room temperature $\left(24^{\circ}\right.$ Celsius). This methodology was important to attend daily to the natural submersion of the specimens and investigate the full change of the solution concentration in the specimens' bodies. In sequence, they were suspended in a grid for 30 days at room temperature to drain the solution excess.

After the solution drainage, the qualitative analysis was started and lasted 365 days. Each specimen was packed in semi-open recipients with identification by the group at room temperature. The routine of the evaluation was conducted biweekly with the simple inspection, manipulation, and comparison about: a) the embalming quality and decomposition process, b) the color, c) the fungus proliferation, d) the flexibility, and e) the pliability to dissect after conversion. The pliability was verified by performing a stratum dissection in the anterolateral abdominal wall, in all specimens, at the end of the experiment (Figure 2). 
Figure 2 - Photographs of the specimens of Control group (C), G1, and G2 after 365 days of the experiment with partial dissection.



Note the relative pliability of the specimens in the dissection of the skin, subcutaneous tissue, and anterior wall of the abdomen. Scale bar $2 \mathrm{~cm}$. Source: Authors.

\section{Results}

The natural submersion of the specimens occurred by the 30th day in the experimental groups with no differences between them. Both techniques allowed the specimens to remain in the environment without the occurrence of dryness, fungal proliferation, and decomposition. Likewise, these specimens showed no odor features compared to the control, not even the formalin initially infused.

The decrease in pliability and the darkening of the viscera were verified in G1 when compared to the control. However, they still allowed free manipulation and dissection (Figure 1). The brownish and yellowish tones allowed a more natural appearance to the specimens. Organs such as the heart, the liver, and the kidneys were similar to the color of the living compared to control (Figure 1).

The specimens in G2 were darker and stiffer when compared to G1, making it difficult to dissect after conversion: these attributes allowed us to choose the G1 solution as the most successful. In addition, the technique applied in G1 showed greater differentiation between the anatomical structures, being more appropriate for performing other dissections (Figure 2).

\section{Discussion}

The main result of this report was to present a solution as an alternative method to convert formalin-embalmed specimens into less harmful, odor-free, and color-realistic specimens for museums, expositions, and lectures made in low-cost and commercially- accessible materials.

The proposition of a single solution able to convert a formalin-embalmed cadaver capable to eliminate any equipment or the maintenance in immersion, and still, maintain the texture and color of the anatomical structures such as in the living, is not a simple task, but have been extensively explored by several research groups in the world.

The analysis of the specimen aspect depending on the embalming technique, the goal of the specimen, and, even, the observer perception (Joy Y. Balta et al., 2015). Thus, we focus on the analysis of the pros and cons of the most popular anatomical methods and reagents to develop the discussion, keeping the aim of the study. 
The use of glycerin and ethanol to preserve biological materials are potential alternatives to formaldehyde and recognized as such for a long time. Since that, our experiment performed a balance between them. The main reason for that is the decreased level of toxicity and the long-term preservation that combines flexible tissues and good cosmetic appearance (Hammer et al., 2011, 2012). On the other hand, the exclusive use of ethanol as an embalming agent requires an expensive preparation of the laboratory to avoid incendiary accidents. For this reason, the use of glycerin has been better received in Brazil, although its solid use and in a long time results in extremely darkened visualization of the cadaveric material, which negatively impacts the study and the exposition. Also, the ambient temperature, which is in a tropical country like Brazil varies but usually has an average of $22-26^{\circ} \mathrm{C}\left(72-79^{\circ} \mathrm{F}\right)$, culminates in wet and slippery specimens in the case of glycerin, and may increase the risk of fires with ethanol preservation.

The Thiel method is recognized as being an alternative with a low level of toxicity and a high level of proximity to the texture and color of living tissue (Hammer et al., 2015; Hunter et al., 2014). The criticism of this method is in the high-cost for preparation, the low durability of the cadavers, the need for expensive maintenance to extend its durability, and paradoxically, the personal discomfort issues related to the very close appearance to the living (Joy Y. Balta et al., 2015).

A saturated salt solution (35.89g sodium chloride per $100 \mathrm{ml}$ at $20^{\circ} \mathrm{C}$ ) was also proposed for embalming, maintenance, conversion, and medical training. Showed great financial advantage by using only water and salt, keeping the texture and color of the cadavers of humans and animals very close to the living ones. However, there are uncertainties about their durability and there is a need for refrigerators or containers for immersion and cadaver maintenance, creating the necessity for lifting equipment (Burns et al., 2018; Hayashi et al., 2014; Homma et al., 2019; Lombardero et al., 2017).

After visualized these aspects, our work aimed to initiate a study on methods to convert formalin-embalmed biological specimens to significantly decrease these elements, mainly considering the Brazilian reality. The proposed solutions had two basic characteristics: an antimicrobial substance and an embalm and/or maintainer substance. Although both characteristics were preliminarily achieved with formalin embalming (J. Y. Balta et al., 2019), the maintenance of the specimens without immersion in maintaining-solution, reduction of toxicity, and improvement of color and pliability were tested with the proposed solutions with satisfactory results.

In $\mathrm{G} 2$ we mainly tested the influence of $\mathrm{pH}$ and the compound of isothiazolinones and halogenated derivatives which we could not find good results. We believed in these two elements to allow the optimization of the enzymatic activity responsible for the autolysis and decomposition of the tissue microenvironment, which would result in greater flexibility of the anatomical structures. It may have occurred that the isothiazolinones kept the control in fungus proliferation since the presence of fungus in the G2 specimens was not observed; however, this result was also archived in the G1 experiment with sodium chloride, as already recognized in the literature (Lombardero et al., 2017). Even though the isothiazolinones have recognized efficiency as formaldehyde substitute and as antimicrobials for industrial purposes (Lucchesi et al., 2012), including in the food industry, in our observations was not considered as a factor of distinction. In addition, our observations allowed us to believe that this compound may have been responsible to increase the rigidity and darkening of specimens in G2.

In our search, we could found two types of techniques that are completely free of formalin in all embalming steps in the literature: frozen sections and the injection of N-vynil-2-pyrrolidone (NVP)(Haizuka et al., 2018). The first one adds the risk of infections by the decomposition and the need for large freezers for maintenance. The second one was recently published and we can consider that may have achieved a similar purpose of ours. The human cadavers were injected only with NVP and $0.1 \% \mathrm{~N}, \mathrm{~N}$-dibutyl-phenylenediamine (mean concentration of $10 \%$ - body mass-dependent) and kept in plastic bags with 5 liters of this solution at $5 \%$ concentration. This method showed an impressive advantage over articular mobility, dissection, and color of the specimens, with no signs of decomposition and no need for expensive equipment. Those results make us 
believe that the NVP method achieves the aim purpose in our project, although they do not convert a previously formalinembalmed cadaver with this technique, which may be carried out in a further project.

The use of NVP is promising, especially for medical training although the technique has revealed that the keratinous layer of the skin was partially peeled off in all cases, the cadavers had the reduction of the subcutaneous fat in the orbit and the viscera, and the intercostal spaces in thoracic and abdominal walls sagged downwards (Haizuka et al., 2018). In comparison, our solution does not reveal any of these trammels in the specimens.

\section{Conclusion}

Our results showed a decrease in toxicity, a darkening in the viscera, and a decreased in pliability compared with the control: these points should be focused on the next experiments. On the other hand, after 365 days of the experiment, the specimens were not altered from the beginning state in the qualitative analyses, being considered stable, mainly in the G1. This allows us to state that this solution could be used in anatomical specimens for classes and expositions, effectively reducing the unhealthy environment, the risk of accidents with formalin or alcohol-containing containers, controlling the fungus proliferation and the decomposition process, and to convert the traditional formalin-embalmed specimens. Besides, institutions could isolate the embalming room from the specimens' collection and/or exhibition area, reducing risks and unhealthiness in classes and visitations.

\section{Acknowledgments}

We greatly appreciate the technicians in the Department of Morphology (Universidade Federal do Espirito Santo) for their assistance with the materials.

\section{References}

Balta, J. Y., Cryan, J. F., \& O'Mahony, S. M. (2019). The antimicrobial capacity of embalming solutions: A comparative study. Journal of Applied Microbiology, 126(3), 764-770. https://doi.org/10.1111/jam.14191

Balta, Joy Y., Lamb, C., \& Soames, R. W. (2015). A pilot study comparing the use of Thiel- and formalin-embalmed cadavers in the teaching of human anatomy. Anatomical Sciences Education, 8(1), 86-91. https://doi.org/10.1002/ase.1470

Baptista, J. da S., Leite, R. de S., de Oliveira, G. B., Seyfert, C. E., \& Marega, P. (2010). Desafios na Implantação de um Laboratório de Anatomia Humana no Interior do Nordeste Paraibano. O Anatomista, 3.

Brenner, E. (2014). Human body preservation - old and new techniques. Journal of Anatomy, 224(3), 316-344. https://doi.org/10.1111/joa.12160

Burns, D. M., Bell, I., Katchky, R., Dwyer, T., Toor, J., Whyne, C. M., \& Safir, O. (2018). Saturated Salt Solution Cadaver-Embalming Method Improves Orthopaedic Surgical Skills Training. The Journal of Bone and Joint Surgery. American Volume, 100(15), e104. https://doi.org/10.2106/JBJS.17.01256

Chafin, D., Theiss, A., Roberts, E., Borlee, G., Otter, M., \& Baird, G. S. (2013). Rapid Two-Temperature Formalin Fixation. PLoS ONE, 8(1). https://doi.org/10.1371/journal.pone.0054138

Gilbert, M. T. P., Haselkorn, T., Bunce, M., Sanchez, J. J., Lucas, S. B., Jewell, L. D., Van Marck, E., \& Worobey, M. (2007). The isolation of nucleic acids from fixed, paraffin-embedded tissues-which methods are useful when? PloS One, 2(6), e537. https://doi.org/10.1371/journal.pone.0000537

Haizuka, Y., Nagase, M., Takashino, S., Kobayashi, Y., Fujikura, Y., \& Matsumura, G. (2018). A new substitute for formalin: Application to embalming cadavers. Clinical Anatomy, 31(1), 90-98. https://doi.org/10.1002/ca.23011

Hammer, N., Löffler, S., Bechmann, I., Steinke, H., Hädrich, C., \& Feja, C. (2015). Comparison of modified Thiel embalming and ethanol-glycerin fixation in an anatomy environment: Potentials and limitations of two complementary techniques. Anatomical Sciences Education, 8(1), 74-85. https://doi.org/10.1002/ase.1450

Hammer, N., Löffler, S., Feja, C., Bechmann, I., \& Steinke, H. (2011). Substitution of formaldehyde in cross anatomy is possible. Journal of the National Cancer Institute, 103(7), 610-611. https://doi.org/10.1093/jnci/djr035

Hammer, N., Löffler, S., Feja, C., Sandrock, M., Schmidt, W., Bechmann, I., \& Steinke, H. (2012). Ethanol-glycerin fixation with thymol conservation: A potential alternative to formaldehyde and phenol embalming. Anatomical Sciences Education, 5(4), 225-233. https://doi.org/10.1002/ase.1270 
Research, Society and Development, v. 10, n. 1, e21510111575, 2021

(CC BY 4.0) | ISSN 2525-3409 | DOI: http://dx.doi.org/10.33448/rsd-v10i1.11575

Hayashi, S., Homma, H., Naito, M., Oda, J., Nishiyama, T., Kawamoto, A., Kawata, S., Sato, N., Fukuhara, T., Taguchi, H., Mashiko, K., Azuhata, T., Ito, M., Kawai, K., Suzuki, T., Nishizawa, Y., Araki, J., Matsuno, N., Shirai, T., \& Itoh, M. (2014). Saturated Salt Solution Method: A Useful Cadaver Embalming for Surgical Skills Training. Medicine, 93(27), e196. https://doi.org/10.1097/MD.0000000000000196

Homma, H., Oda, J., Sano, H., Kawai, K., Koizumi, N., Uramoto, H., Sato, N., Mashiko, K., Yasumatsu, H., Ito, M., Fukuhara, T., Watanabe, Y., Kim, S., Hayashi, S., Kawata, S., Miyawaki, M., Miyaso, H., \& Itoh, M. (2019). Advanced cadaver-based educational seminar for trauma surgery using saturated salt solution-embalmed cadavers. Acute Medicine \& Surgery, 6(2), 123-130. https://doi.org/10.1002/ams2.390

Hunter, A., Eisma, R., \& Lamb, C. (2014). Thiel embalming fluid-A new way to revive formalin-fixed cadaveric specimens. Clinical Anatomy (New York, N.Y.), 27(6), 853-855. https://doi.org/10.1002/ca.22392

International Agency for Research on Cancer (Org.). (2006). IARC monographs on the evaluation of carcinogenic risks to humans, volume 88, Formaldehyde, 2-Butoxyethanol and 1-tert-Butoxypropan-2-ol: This publication represents the views and expert opinions of an IARC Working Group on the Evaluation of Carcinogenic Risks to Humans, which met in Lyon, 2 - 9 June 2004. IARC.

Lombardero, M., Yllera, M. M., Costa-e-Silva, A., Oliveira, M. J., \& Ferreira, P. G. (2017). Saturated salt solution: A further step to a formaldehyde-free embalming method for veterinary gross anatomy. Journal of Anatomy, 231(2), 309-317. https://doi.org/10.1111/joa.12634

Lorenzoni, D.-C., Pinheiro, L.-P., Nascimento, H.-S., Menegardo, C.-S., Silva, R.-G., Bautz, W.-G., Henriques, J.-F., Almeida-Coburn, K.-L., \& da Gama-deSouza, L.-N. (2017). Could formaldehyde induce mutagenic and cytotoxic effects in buccal epithelial cells during anatomy classes? Medicina Oral, Patología Oral y Cirugía Bucal, 22(1), e58-e63. https://doi.org/10.4317/medoral.21492

Lucchesi, E. G., Eguchi, S. Y., \& Moraes, A. M. (2012). Influence of a triazine derivative-based biocide on microbial biofilms of cutting fluids in contact with different substrates. Journal of Industrial Microbiology \& Biotechnology, 39(5), 743-748. https://doi.org/10.1007/s10295-011-1081-x

Patel, K. M., \& Moxham, B. J. (2008). The relationships between learning outcomes and methods of teaching anatomy as perceived by professional anatomists. Clinical Anatomy (New York, N.Y.), 21(2), 182-189. https://doi.org/10.1002/ca.20584

Rodrigues, H., Tose, D., Musso, F., Azeredo, R., \& Mayer, W. (2010). Técnicas Anatômicas (4a ed.). GM gráfica e editora.

Tamayo-Arango, L., \& Garzón-Alzate, A. (2018). Preservation of Animal Cadavers with a Formaldehyde-free Solution for Gross Anatomy. Journal of Morphological Sciences, 35(2), 136-141. https://doi.org/10.1055/s-0038-1669434

Yörükoglu, K., Cingöz, S., Agilkaya, S., \& Aydin, I. (2013). The effect of the alternative solutions to formaldehyde and xylene on tissue processing. Indian Journal of Pathology and Microbiology, 56(3), 221. https://doi.org/10.4103/0377-4929.120371 